N. Kalyuzhna ${ }^{1}$, Dr. Sc. (Econ.), Assoc. Prof., orcid.org/0000-0003-0513-705X, A. Khodzhaian ${ }^{2}$, Dr. Sc. (Econ.), Prof., orcid.org/0000-0002-3015-1016, P. Nebotov ${ }^{3}$, Cand. Sc. (Econ.), orcid.org/0000-0002-6260-4374
1 - Kyiv National University of Trade and Economics, Kyiv, Ukraine, e-mail: kalujnaya.natalya@gmail.com

2 - Taras Shevchenko National University of Kyiv, Ukraine, e-mail: alina_khodzhaian@ukr.net

3 - State Research Institute of Informatization and Modeling of Economics, Kyiv, Ukraine, e-mail: petr_nebotov@ukr.net

\title{
THE WTO TOOLKIT IN REGULATING INTERSTATE TRADE AND ECONOMIC COOPERATION
}

Purpose. To determine the idea and efficiency of the WTO toolkit as a resource to prevent and regulate trade disputes arising in the process of interstate trade and economic cooperation.

Methodology. Methods of analysis and synthesis, used to systemize data concerning inflow of notifications and applications, intended to regulate trade disputes within the WTO during 1995-2018, have become a methodological basis of the research. Formalization of criteria of the WTO toolkit efficient use is implemented with the help of mathematical modeling method; and a method of static analysis is applied to support a rising linear trend in the context of the dynamics of annual number of the WTO notifications during 1995-2018.

Findings. The defining role by the WTO in the process of interstate trade and economic cooperation is substantiated. It is demonstrated that minimization of the number of interstate disputes in the trade sphere as well as their intensity degree is the objective of the WTO toolkit use. The idea of notification system and mechanism to regulate trade disputes as the key components of the toolkit preventing them within the WTO is considered. An efficiency criterion of the WTO notification system as the increased number of the applied notifications is identified; its execution during 1995-2018 is confirmed. Both static and dynamic criteria of the efficiency of the mechanism, resolving trade disputes by the WTO, are proposed. Prevailing execution of the static criterion is supported which speaks for the efficiency of the mechanism to regulate disputes as the tool of the WTO global trade. Nonexecution of the dynamic criterion is demonstrated which may be interpreted as a lack of cumulative effect by the accumulated practices intended to regulate trade disputes. Complex criterion of the WTO toolkit efficient use is proposed; its execution during 1995-2018 is analyzed. Priority tendencies to regulate interstate trade and economic cooperation on the part of the WTO are determined.

Originality. For the first time, methodological approach to evaluate efficiency of the WTO toolkit as a resource to regulate interstate trade and economic cooperation has been proposed. The approach is based upon the following: substantiation of such efficiency criteria use for trade protection as a notification system and a mechanism to regulate trade disputes by the WTO; formation of a complex efficiency criterion to apply for regulation of trade disputes by the WTO; formulation of complex criterion of efficient use of the WTO tools; determination of quantative equivalents of the proposed criteria, and analysis of their execution during 1995-2018.

Practical value. The proposed methodological approach may be applied to evaluate efficiency of the WTO toolkit concerning the global trade regulation as for the prevention and negotiation of interstate trade disputes.

Keywords: global trade regulations, trade dispute, trade and economic cooperation, notification system, efficiency coefficient

Introduction. Activization and impetuous expansion of tendencies of protectionism and antiglobalism in the context of foreign policy of states results in the significant transformation of interstate trade conditions. Despite effort by the WTO to provide transparency of foreign trade relations, and liberization in trade conditions, countries demonstrate their willingness to protect by all means interests of domestic manufacturers both in national and in external markets. Against the backdrop of readiness of subjects of international trade to vindicate their own interests even at the expense of discrimination of trading partners, the number of interstate trade disputes increases and the WTO role in their regulation and prevention becomes more important. Notification system and a mechanism to regulate trade disputes should be meant among the key WTO tools solving problems of international cooperation to avoid escalation of interstate trade tension.

Literature review. Such national and world scientists as R. Wolfe [1], I. Burakovsky [2], N. Kalyuzhna [3], T. Gordeeva [4], T. Dillon [5], T. Payosova [6], L. Tykhonchuk [7], K. Fung [8], K. Flissak [9], S. Charnovitz [10] and others have been engaged in the study of essence and specific features of application of tools of global the WTO trade. On the whole, scholars indisputably recognize a leading WTO role as for its favouring to the foreign trade cooperation of states and development of regulatory environment of interstate trade $[1,3-5,7,9]$. At the same time, scientists admit current aggravation of problems concerning the WTO efficiency. Thus, S. Charnovitz [10] notes the necessity to adapt the WTO activities to the latest

(c) Kalyuzhna N., Khodzhaian A., Nebotov P., 2020 globalization challenges. T. Payosova [6] believes that the mechanism of regulation of trade disputes is under crisis resulting from imperfection of certain WTO rules. Due to their varying interpretation, more and more often precedents of politically motivated dispute regulation by the WTO are set to the advantage of stronger international trade participants. Papers $[5,8]$ note that lobbying for the interests of the leading players of the world policy within the WTO results in the failure of negotiations as for the regulation of trade disputes, and their escalation. Once again, the fact emphasizes topicality of the study concerning the efficiency of the WTO tools as a resource to prevent and regulate trade disputes.

While presenting detail characterization and recognizing importance of the tools for international trade regulation [7, 9], scholars often ignore problems of their efficiency as for the influence on trade and economic relations [7, 9]. Theoretical and practical results of study of a concept of international trade disputes, obtained by T. Gordeeva, are worth noticing. The empirical study, concerning dependence of trade level among the WTO member countries and the number of complaints lodged to Dispute Settlement Body of the Organization, has helped the author to make a conclusion concerning moderate inverse correlation between the indices [4]. Namely, correlation coefficient between annual global trade and the number the recorded trade disputes is $(-0.67)$. Such a result may be interpreted as an evidence of moderate WTO efficiency as for the prevention of interstate trade disputes. However, in spite of doubtless recognition of positive role of the WTO in the process of mending trade and economic interstate relations, the system methodological foundations, concerning the 
efficiency of engaging countries in the system of global trade law, are not available.

Purpose is to determine the idea and efficiency of the WTO tools as a resource of prevention and regulation of trade disputes arising in the process of interstate trade and economic cooperation.

Results. Toolkit to regulate global trade laws has been implemented and is applied successfully in the context of the WTO. Notification system is one of the key components of the toolkit. The notification system enables the WTO countries to comment on draft laws or other legislative instruments, planned by member countries, before they are approved or to start discussions with competent authorities of corresponding countries as for the possibility to introduce amendments and alternations. Notification process transparency helps consider it as a basis to provide efficiency of trade and economic cooperation at the expense of favouring openness, and predictability of international trade procedures.

The prevailing majority of the notifications concern the Agreement on Technical Barriers to Trade (TBT), and Agreement on Sanitary and Phytosanitary Measures (SPS). The SPS Agreement favors control of quality and safety of goods in every member country of the WTO. When agricultural products are imported, the Agreement lays down the rules of use of sanitary and phytosanitary measures aimed at protection of human life and health, protection of animals and plants while providing safety of food products, also preventing disease of plant and animal origin from getting to the territory of the WTO member countries. The TBT Agreement mainly concerns homeland security, unfair practice prevention, and environmental protection.

To evaluate the WTO notification system influence on the interstate trade and economic cooperation, it is necessary to determine its efficiency criteria. We think that annual ascending dynamics of the submitted will prove the efficient use of the benefits of the system. That will mean system increase in awareness among the WTO member countries as for the rules and regulations of domestic and export sales, gradual increase in transparency of foreign trade policy of states by means of publication of laws, regulatory acts, decisions, regulations, and international agreements dealing with marketing changes. Theoretically, requirement for annual minimization of the notification number and its tending to zero may become the criterion which would be indicative of changeless foreign trade policy and necessity for mutual reports concerning their notification. However, it is understood that in practice the situation is unachievable when, on the contrary, the proposed criterion of annual increase in the notification number will be indicative of active use of the WTO mechanisms by countries, and their desire to make any changes in foreign trade policy transparent and open.

Hence, the criterion of efficiency of the WTO notification system can be determined as an annual increase in the number of the submitted notifications

$$
\Delta k=k_{i}-k_{i-1} \succ 0,
$$

where $\Delta k$ is annual increase in the number of notifications in the context of the WTO system; $k_{i}$ is the number of notifications submitted by the WTO member countries during the $i^{\text {th }}$ year; and $k_{i-1}$ is the number of notifications submitted by the WTO member countries during the $(i-1)^{\text {th }}$ year.

Approximation possibility of the related time series by means of linear function will correspond to the requirements of system annual increase in the number of notification. Table 1 demonstrates the results of approximation by means of different functions of time series corresponding to annual number of notifications submitted within the WTO during 1995-2018 (Fig. 1). The data, concerning the number of notifications submitted during the first half of 2019, were not taken into consideration not to misinterpret annual results. Nevertheless, it should be noted that if tendencies of the first half of
Table 1

Approximation results of time series of the annual number of notifications in the context of the WTO during 1995-2018

\begin{tabular}{|l|l|c|}
\hline $\begin{array}{c}\text { Approximation } \\
\text { type }\end{array}$ & \multicolumn{1}{|c|}{ Equations of the trend line } & $\begin{array}{c}\text { Determination } \\
\text { coefficient } R^{2}\end{array}$ \\
\hline Exponential & $y=429.04 e^{0.0647 x}$ & 0.8824 \\
\hline Linear & $y=65.063 x+260.04$ & 0.908 \\
\hline Logarithmic & $y=485.591 \ln (x)-35.12$ & 0.6819 \\
\hline $\begin{array}{l}\text { Second order } \\
\text { polynomial }\end{array}$ & $y=1.6034 x^{2}+24.979 x+433.74$ & 0.8975 \\
\hline Static & $y=295.24 x^{0.5182}$ & 0.7801 \\
\hline
\end{tabular}

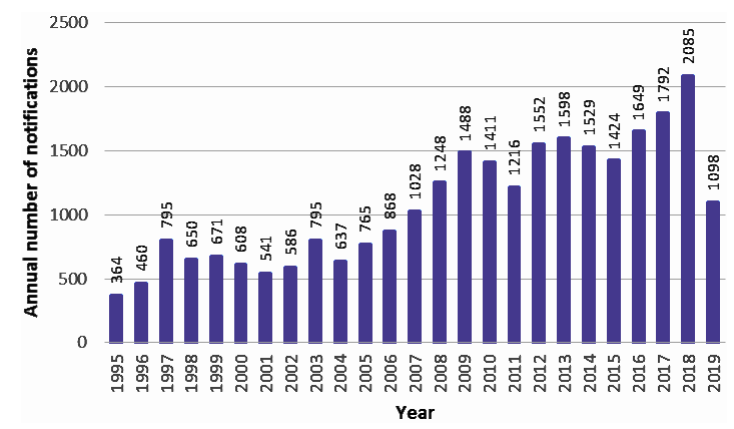

Fig. 1. Notifications by the WTO member countries in terms of TBT/SPS from 01.01.1995 till 31.06.2018 (compiled on the basis of [11])

the year stay constant, at the end of 2019, the residual quantity of notification will exceed the number of notifications in 2018.

As Table 1 explains, the best method to approximate time series of the annual number of notifications is linear function which is supported by determination coefficient maximum $\left(R^{2}=0.908\right)$. The fact helps make a conclusion that ascending linear dynamics in the context of annual increase in the number of notifications which speaks for successful use of the mechanism by the WTO member countries to provide efficiency of their trade and economic cooperation.

The following can be considered as recommendations to support ascending dynamics of the WTO notification number:

- active involvement of the least developed countries in the process of notification exchange by means of rendering technical support and counselling assistance;

- further development of the WTO member countries' cooperation (both at governmental level and at the level of business community) within a system of online notification ePing [12];

- favoring the improvement of organizational management structure as for notification submitting in by the WTO member countries.

Mechanism of dispute settlement is another important tool of the WTO system of global trade law. Dispute settlement is the essential means guaranteeing fulfillment of obligations by the WTO members assumed during trade negotiations owing to hugging the determined procedure. The mechanism of dispute settlement by the WTO remains one of the fundamentals of multilateral trade system; the increasing number of disputes supports the mechanism importance for the organization members. Statistically, two thirds of the WTO member countries (i.e. 109 of 159) participated in trade disputes as a litigant (complainant, defendant, or third party) [11].

The WTO dispute settlement system is based upon the unified, uniform, and transparent rules for all members despite their political heft or economic power. Moreover, information exchange in terms of the procedure, intended to settle trade disputes, makes it possible to settle efficiently potential 
disputes, decreases uncertainty, and increases predictability of foreign trade policy being a stimulus for commercial business and investment.

Starting from 1995, analysis of data, concerning settlement of trade disputes in the context of the WTO, demonstrates that 587 disputes were submitted [11]. Annual dynamics of submitting consultative requests (Fig. 2) speaks for their increased number concerning consultations as of the end of 2018, which means indirectly escalation of interstate trade tension due to strengthening of protectionist tendencies in foreign trade policy.

Statistically, the absolute majority of the trade disputes are solved at the consultative stage or at the stage of Expert Group formation; a minor number of disputes is resolved by means of compensation on the part of a losing side. The fact speaks for the efficiency of consultative mechanism, applied by the WTO member countries, preceding initiation of a dispute as a trade conflict. The mechanism is absolutely public and transparent; moreover, it involves the possibility to involve any country and/or international body to favor establishing contacts and questing for a compromise and/or as an observer. We believe that just the number of trade disputes, solved at a consultation stage, may be interpreted as an efficiency index of the appropriate WTO mechanism. Owing to the public and transparent consultations, the WTO member countries can come to an agreement as for solving the trade dispute (statistically, the majority of cases are exhausted in such a way) without bringing the disputes up to a more conflict stage. Specifically, for the most part, the successful arrangement results from the achievement of mutually acceptable solution at the initial consultation stage when further development of the formal WTO procedure takes place if worse comes to worst.

Taking into consideration the thoughts, we can formulate the efficiency criterion of the mechanism to resolve disputes in the context of the WTO as maximization of the number of trade disputes which were regulated (i.e. resolved/suspended/ abandoned) annually at the consultation stage

$$
K_{P(i)}=\frac{n_{C O N S(i)}}{N_{i}} \cdot 100 \% \rightarrow \max ,
$$

where $K_{P(i)}$ is efficiency coefficient of a mechanism to resolve trade disputes by the WTO during the $i^{\text {th }}$ year; $n_{\text {CONS(i) }}$ is the number of trade disputes during the $i^{\text {th }}$ year resolved at a consultation stage; $N_{i}$ is the total number of trade disputes resolved in the context of the WTO during the $i^{\text {th }}$ year.

Table 2 demonstrates calculation of the percentage of trade disputes regulated annually at different stages of the total procedure in the context of the total number of disputes. It is obvious that qualitative equivalent of the proposed $K_{P(i)}$ coefficient is the share of trade disputes resolved by the WTO at the consultation stage of the total number of disputes resolved annually. Such disputes should be added by those resolved with the help of bilateral consultations; those which were terminated at the stage with no notifications to the WTO; and those abandoned by a complainant. As Table 2 explains, the requirement

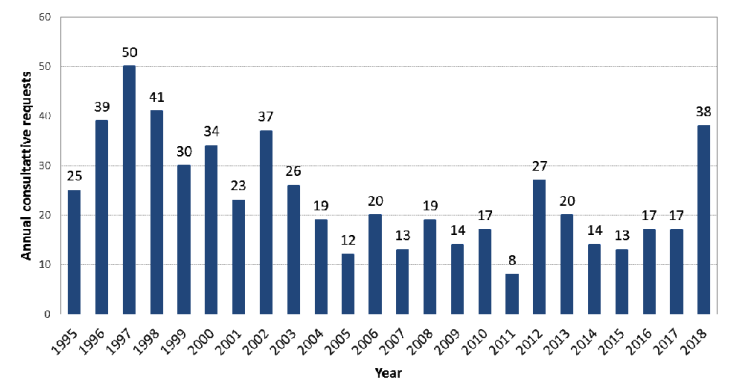

Fig. 2. Dynamics of submitting consultative requests to the WTO concerning settlement of trade disputes during 1995-2018 [11] for minimization of share of disputes, regulated at the consultation stage is mainly fulfilled, unexceptionally a period from 1995 till 2002. The share of trade disputes, regulated at a consultation stage (i. e. efficiency coefficient) varies from 90.91 per cent in 1996 to 45.24 per cent in 2001. In subsequent years, high values of the efficiency coefficient continue in general but there are certain exclusions when the maximum dispute number is regulated at a stage of the Expert Group activities (years of 2011, and 2018); contribution of an Appeal Body (years of 2014, and 2015); or implementation of its decisions (years of 2009 , 2011, and 2014). However, the annual number of disputes either resolved or terminated at a consultation stage is noteworthy. It means that in the majority of cases, the WTO member countries efficiently use the advantages of a mechanism intended to resolve disputes coming to terms before the situation becomes more conflict.

Values of the efficiency coefficient of a mechanism to regulate trade disputes by the WTO can be considered as its annual static characteristic, when provision of ascending dynamics of the efficiency coefficient $K_{P(i)}$ during the period under study should be considered as a dynamic one

$$
\Delta K_{P}=K_{P(i)}-K_{P(i-1)} \succ 0,
$$

where $\Delta K_{P}$ is increase in the efficiency coefficient of a mechanism to regulate trade disputes; $K_{P(i)}$ is the efficiency coefficient value during the $i^{\text {th }}$ year; $K_{P(i-1)}$ is the efficiency coefficient value during the $(i-1)^{\text {th }}$ year.

Annual increase in the share of trade disputes, resolved at the stage of consultations, would speak for the accumulated experience as for the WTO mechanism use owing to transparency, openness, and publicity. Nevertheless, Fig. 3 shows that the share of dynamics of the trade disputes, resolved at the consultation stage (i.e. qualitative equivalent of the efficiency coefficient), does not have any increasing tendency.

Fig. 4 systemizes results of analysis of the WTO toolkit essence as well as its role as for providing efficiency of interstate trade and economic cooperation. We think the notification system and a mechanism to regulate trade disputes, being the key components of the WTO toolkit, have different application targets. Namely, involvement of countries in the notification system is aimed at the prevention of foreign trade disputes by means of sharing information concerning changes in foreign trade policy of the WTO members. On the contrary, the mechanism to resolve trade disputes is applied if interstate foreign trade dispute has already arisen, which can be confirmed by claims on the part of complainant country on a defendant country. Trade dispute may originate if the defendant country implements measures of foreign trade policy which are considered by the complainant as those being threatened for national economic interests, i.e. export restrictions, specific requirements, discrimination duties/exactions, anti dumping measures, trade/transit embargo and others. If the countries cannot come to terms as for the dispute resolving during a procedure of the trade dispute regulation, the dispute may escalate up to sterner forms of foreign trade confrontation (i.e. trade war). However, as it has been noted, in the majority of cases, the WTO member countries come to the terms at the consultation stage resolving trade disputes before their transition to more conflict stage.

Generalization of the study results helps determine complex criterion of the WTO toolkit application which can be formulated as maximization of the number of trade disputes resolved annually at a consultation stage if ascending dynamics of the number of such disputes is provided as well as notifications submitted to the WTO yearly

$$
F_{i}=\left\{\begin{array}{l}
K_{P(i)}=\frac{n_{C O N S(i)}}{N_{i}} \cdot 100 \% \rightarrow \max \\
\Delta K_{P}=K_{P(i)}-K_{P(i-1)} \succ 0 \\
\Delta k=k_{i}-k_{i-1} \succ 0
\end{array},\right.
$$


Percentage of trade disputes, regulated at different stages of the total WTO procedure during 1995-2018, \% (the calculations were performed according to [11] data)

\begin{tabular}{|c|c|c|c|c|c|c|c|c|}
\hline \multirow{2}{*}{ Stages of the procedure } & \multicolumn{8}{|c|}{ Years } \\
\hline & 1995 & 1996 & 1997 & 1998 & 1999 & 2000 & 2001 & 2002 \\
\hline Consultations/abandoned according to mutual agreement & 87.50 & 90.91 & 71.43 & 72.00 & 54.55 & 48.65 & 45.24 & 50.00 \\
\hline Activities by an Expert Group & 12.50 & 0.00 & 0.00 & 0.00 & 4.55 & 5.41 & 2.38 & 4.55 \\
\hline Appeal Body (AB) contribution & 0.00 & 0.00 & 3.57 & 12.00 & 0.00 & 5.41 & 14.29 & 9.09 \\
\hline Implementation of decisions by $\mathrm{AB}$ & 0.00 & 9.09 & 21.43 & 14.00 & 36.36 & 27.03 & 30.95 & 36.36 \\
\hline Providing compliance with $\mathrm{AB}$ decisions & 0.00 & 0.00 & 0.00 & 0.00 & 0.00 & 5.41 & 4.76 & 0.00 \\
\hline Reappeal (if available) & 0.00 & 0.00 & 0.00 & 0.00 & 0.00 & 0.00 & 2.38 & 0.00 \\
\hline Expiration of adjudication & 0.00 & 0.00 & 3.57 & 2.00 & 4.55 & 8.11 & 0.00 & 0.00 \\
\hline Total & 100.0 & 100.0 & 100.0 & 100.0 & 100.0 & 100.0 & 100.0 & 100.0 \\
\hline \multirow{2}{*}{ Stages of the procedure } & \multicolumn{8}{|c|}{ Years } \\
\hline & 2003 & 2004 & 2005 & 2006 & 2007 & 2008 & 2009 & 2010 \\
\hline Consultations/abandoned according to mutual agreement & 28.00 & 55.56 & 39.13 & 50.00 & 42.86 & 48.00 & 31.25 & 53.33 \\
\hline Activities by an Expert Group & 8.00 & 0.00 & 4.35 & 7.14 & 14.29 & 0.00 & 6.25 & 0.00 \\
\hline Appeal Body (AB) contribution & 40.00 & 5.56 & 17.39 & 0.00 & 0.00 & 20.00 & 18.75 & 6.67 \\
\hline Implementation of decisions by $\mathrm{AB}$ & 16.00 & 27.78 & 39.13 & 35.71 & 14.29 & 20.00 & 37.50 & 40.00 \\
\hline Providing compliance with $\mathrm{AB}$ decisions & 4.00 & 0.00 & 0.00 & 0.00 & 14.29 & 0.00 & 0.00 & 0.00 \\
\hline Reappeal (if available) & 4.00 & 11.11 & 0.00 & 7.14 & 7.14 & 0.00 & 0.00 & 0.00 \\
\hline Expiration of adjudication & 0.00 & 0.00 & 0.00 & 0.00 & 7.14 & 12.00 & 6.25 & 0.00 \\
\hline Total & 100.0 & 100.0 & 100.0 & 100.0 & 100.0 & 100.0 & 100.0 & 100.0 \\
\hline \multirow{2}{*}{ Stages of the procedure } & \multicolumn{8}{|c|}{ Years } \\
\hline & 2011 & 2012 & 2013 & 2014 & 2015 & 2016 & 2017 & 2018 \\
\hline Consultations/abandoned according to mutual agreement & 16.67 & 54.84 & 53.85 & 18.18 & 21.05 & 35.00 & 42.11 & 23.53 \\
\hline Activities by an Expert Group & 33.33 & 3.23 & 15.38 & 9.09 & 5.26 & 20.00 & 10.53 & 45.10 \\
\hline Appeal Body (AB) contribution & 16.67 & 0.00 & 0.00 & 36.36 & 47.37 & 20.00 & 26.32 & 21.57 \\
\hline Implementation of decisions by $\mathrm{AB}$ & 33.33 & 41.94 & 23.08 & 27.27 & 0.00 & 0.00 & 5.26 & 0.00 \\
\hline Providing compliance with $\mathrm{AB}$ decisions & 0.00 & 0.00 & 0.00 & 9.09 & 10.53 & 10.00 & 10.53 & 5.88 \\
\hline Reappeal (if available) & 0.00 & 0.00 & 7.69 & 0.00 & 15.79 & 10.00 & 5.26 & 3.92 \\
\hline Expiration of adjudication & 0.00 & 0.00 & 0.00 & 0.00 & 0.00 & 5.00 & 0.00 & 0.00 \\
\hline Total & 100.0 & 100.0 & 100.0 & 100.0 & 100.0 & 100.0 & 100.0 & 100.0 \\
\hline
\end{tabular}

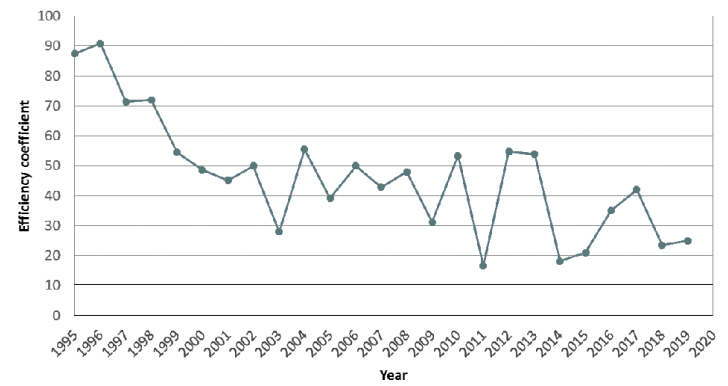

Fig. 3. Dynamics of the efficiency coefficient of a mechanism to regulate trade disputes by the WTO during 1995-2019

where $F_{i}$ is efficiency criterion of the WTO toolkit application during the $i^{\text {th }}$ year; $K_{P(i)}, K_{P(i-1)}$ is efficiency coefficient of trade disputes regulated by the WTO during the $i^{\text {th }}$ year and $(i-1)^{\text {th }}$ year respectively; $n_{\text {CONS( }(i)}$ is the number of trade disputes in terms of the $i^{\text {th }}$ year regulated at the stage of consultations; $N_{i}$ is the total number of trade disputes regulated in the context of the WTO during the $i^{\text {th }}$ year; $k_{i}, k_{i-1}$ is the number of notifications submitted by the WTO member countries during the $i^{\text {th }}$ year and $(i-1)^{\text {th }}$ year respectively.
Analyze adhering to the complex efficiency criteria of the WTO toolkit application during 1995-2018 being equal to simultaneous meeting all the three conditions of formula (4) during a certain year. As the data from Table 3 attest, meeting the conditions of the complex efficiency criterion of the WTO toolkit application can be described by the four linguistic variables:

- "meeting the conditions" - simultaneous fulfillment of the three conditions forming the complex criterion of the WTO toolkit application, namely: maximal share of trade disputes regulated at the stage of consultation of the total of the disputes with active status during a certain year; available ascending dynamics in the context of the amount of disputes regulated at a consultation stage to compare with a previous year; and availability of ascending dynamics as for the number of notifications submitted to the WTO to compare with a previous year;

- "partially meeting the conditions" - simultaneous fulfillment of any two of the three conditions forming the complex efficiency criterion of the WTO toolkit application during a certain year;

- "partially not meeting the conditions" - simultaneous nonfulfilment of any two of the three conditions forming the 


\begin{tabular}{|c|c|c|}
\hline The WTO toolkit & Notification system & Mechanism to resolve trade disputes \\
\hline Application target of the tools & $\begin{array}{c}\text { Prevention of foreign trade } \\
\text { disputes }\end{array}$ & Regulation of foreign trade disputes \\
\hline \multicolumn{3}{|c|}{ Efficiency criteria of the WTO toolkit use } \\
\hline Static criterion & Unavailable & $\begin{array}{l}\text { Maximization of the number } \\
\text { of trade disputes regulated annually } \\
\text { at the stage of consultations }\end{array}$ \\
\hline Dynamic criterion & $\begin{array}{c}\text { Ascending dynamics } \\
\text { of the number of notifications } \\
\text { submitted annually }\end{array}$ & $\begin{array}{c}\text { Ascending dynamics of the } \\
\text { number of trade disputes regulated } \\
\text { annually at the stage of consultations }\end{array}$ \\
\hline \multicolumn{3}{|c|}{ Qualitative equivalent of the efficiency criteria as for the WTO toolkit application } \\
\hline Static criterion & Unavailable & $\begin{array}{c}\text { Efficiency coefficient } \\
\text { of the mechanism to regulate trade } \\
\text { disputes by the WTO during the } i^{\text {th }} \text { year } K_{P(i)}\end{array}$ \\
\hline Dynamic criterion & $\begin{array}{l}\text { Increase in the number } \\
\text { of notifications in the context } \\
\text { of the WTO system }(\Delta K)\end{array}$ & $\begin{array}{l}\text { Increase in the value } \\
\text { of the efficiency coefficient of the mechanism } \\
\text { to regulate trade disputes }\left(\Delta K_{P}\right)\end{array}$ \\
\hline \multicolumn{3}{|c|}{ Following the efficiency criteria as for the WTO toolkit application } \\
\hline Static criterion & Unavailable & Mainly confirmed \\
\hline Dynamic criterion & Confirmed & Unconfirmed \\
\hline
\end{tabular}

Fig. 4. The WTO toolkit intended to provide efficiency of interstate trade and economic cooperation

complex efficiency criterion of the WTO toolkit application during a certain year;

- "not meeting the conditions" - simultaneous nonfulfilment of the three conditions forming the complex efficiency criterion of the WTO toolkit application during a certain year.
Results of analysis of the data, represented in Table 3, help conclude that in the majority of the cases it is possible to state either meeting the conditions of efficiency criteria of the WTO toolkit application during 1995-2018 is complete or a partial one. Only the years of 2011 and 2014 demonstrate simultaneous

Data concerning meeting the conditions of efficiency criteria as for the WTO toolkit application during 1995-2018*

\begin{tabular}{|c|c|c|c|c|c|c|c|c|c|c|c|c|c|c|c|c|c|c|c|c|c|c|c|c|}
\hline \multirow{2}{*}{$\begin{array}{l}\text { Qualitative equivalent of the } \\
\text { efficiency criteria }\end{array}$} & \multicolumn{24}{|c|}{ Years } \\
\hline & $\stackrel{2}{\alpha}$ & よ & $\hat{\sigma}$ & $\stackrel{\infty}{\stackrel{2}{\sigma}}$ & Әे & ஓ्̀ & ஓे & §ั่ & ஜे & $\stackrel{+}{\stackrel{\imath}{े}}$ & 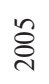 & 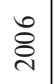 & ڤ્ণ & 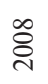 & 穴 & $\stackrel{\circ}{\circ}$ & $\overline{\check{\curvearrowright}}$ & $\stackrel{\sim}{\stackrel{\sim}{*}}$ & 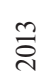 & $\frac{\text { d }}{9}$ & $\stackrel{n}{\stackrel{n}{\sim}}$ & 을 & 혹 & $\stackrel{\infty}{\stackrel{\sim}{\sim}}$ \\
\hline$K_{P(i)}$ & + & + & + & + & + & + & + & + & - & + & + & + & + & + & - & + & - & - & - & - & - & + & + & - \\
\hline$\Delta K_{P}$ & - & + & - & + & - & - & - & + & - & + & - & + & - & + & - & + & - & + & - & - & + & + & + & - \\
\hline$\Delta K$ & - & + & + & - & + & - & - & + & + & - & + & + & + & + & + & + & - & + & + & - & - & + & + & + \\
\hline $\begin{array}{l}\text { Meeting the conditions of the } \\
\text { complex efficiency criteria }\end{array}$ & & 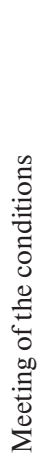 & 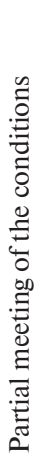 & 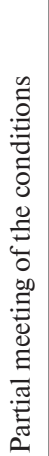 & 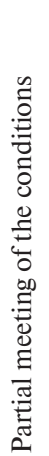 & 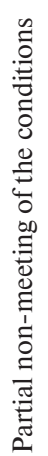 & 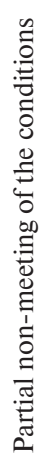 & 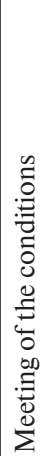 & 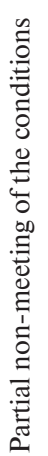 & 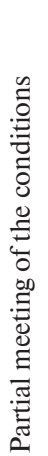 & 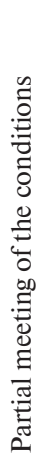 & 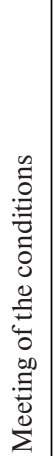 & 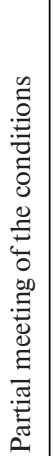 & 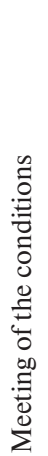 & 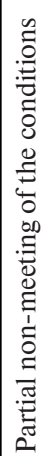 & 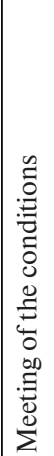 & 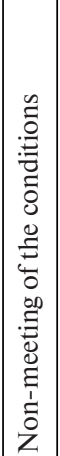 & 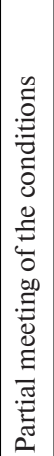 & 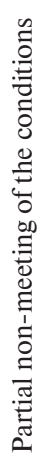 & 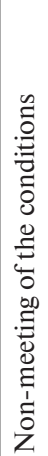 & 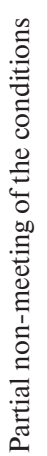 & 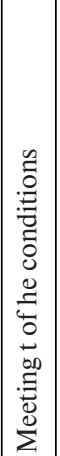 & 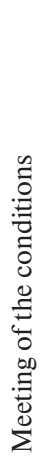 & 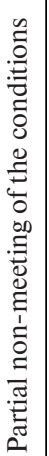 \\
\hline
\end{tabular}

"Symbols: "+" - meeting a certain efficiency criterion of the WTO toolkit application; "_" - not meeting a certain efficiency criterion of the WTO toolkit application 
non-meeting of each of the three conditions of the complex criteria which can be interpreted as unsatisfactory level of application of the WTO toolkit to prevent and regulate trade disputes in the context of the organization. Taking into consideration expansion of protectionism tendencies in foreign trade policy of states, the near future may demonstrate the decreased efficiency application of regulation of trade and economic cooperation by the WTO member countries. Under such conditions, effort by the WTO aimed at prevention and regulation of interstate trade disputes should be focused on following activities:

1) introduction of mechanisms to inform international traders as for the advantages of multilateral WTO trade system;

2) provision of making politically unmotivated decisions while regulating trade disputes;

3) monitoring of foreign trade policy of the WTO member countries in the context of a mechanism of trade policy review to register and prevent protectionist measures;

4) organization and favor conduct of regular intergovernmental negotiations of the WTO member countries to improve efficiency of their trade and economic cooperation.

Conclusions. Results of the study, concerning analysis of essence of the WTO toolkit, confirm its determinative role as for prevention and regulation of interstate trade disputes. Notification system and a mechanism to regulate the trade disputes are the key components of the WTO toolkit influencing directly the efficiency of interstate trade and economic cooperation. Relying upon the result of the study on specific features of application of the components of the WTO toolkits, a system of the criteria efficiency has been proposed and retrospective analysis of meeting their conditions during 1995-2018 was carried out. The calculation results of static and dynamic efficiency criteria of the mechanism regulating trade disputes confirm that the tool of global trade really provide trade dispute resolving at early stages of its escalation. At the same time, it is impossible to state cumulative effect from the accumulated experience trade dispute resolving which is supported by the lack of ascending dynamics in the value of a share of the trade disputes regulated annually at the stage of consultations. Conversely, the recorded ascending dynamics of the number of the submitted notifications confirms system increase in the awareness of the WTO member countries as for the rules and regulations concerning sales in the world market and in the national one as well as their willingness to prevent foreign trade disputes.

The prospects of future studies on the tendency are the development of methodological background to evaluate efficiency of involvement of countries in the system of the WTO Trade Law as a resource to prevent escalation interstate trade disputes and avoid their expanding up to the stage of trade wars.

\section{References.}

1. Wolfe, R. (n.d.). Letting the Sun Shine in at the THE WTO: How Transparency Brings the Trading System to Life. Retrieved form: https://www.theWTO.org/english/res e/ reser_e/ersd201303 e.htm.

2. Membership of Ukraine in the WTO: institutional and economic effects (n.d.). Retrieve from: http://www.ier.com.ua/ files/publications/News/2012/28.11.2012_presentations/Report for presentation 26-11-2012 final.pdf.

3. Kalyuzhna, N. G., \& Yakovchenko, V.S. (2018). The importance of the WTO notification system while providing the efficiency of trade and economic interstate cooperation. Derzhava ta rehiony, 3, 19-24.

4. Gordeeva, T. (n.d.). International trade disputes in the context of the current regulative paradigm. Retrieved from: http:// iepjournal.com/iournals/19/2013 5 Gordeeva.pdf.

5. Dillon, Thomas J. (n.d.). The World Trade Organization: A New Legal Order for World Trade? Retrieved from: https://repository. law.umich.edu/cgi/viewcontent.cgi? article $=1525 \&$ context $=$ mjil. 6. Payosova, T., Hufbauer, G., \& Jeffrey, J. (n.d.). The Dispute Settlement Crisis in the World Trade Organization: Causes and
Cures Retrieved from: https://www.piie.com/system/files/ documents/pb18-5.pdf.

7. Tykhonchuk, L. Kh. (2018). Specific features of implementation of International Standards intended to resolve Ukrainian trade disputes on the basis of processual mechanisms of the WTO. Investytsii: praktyka ta dosvid, 2, 91-96.

8. Fung, K. C., \& Garcia-Herrero, A. (n.d.). Siu Developing countries and the World Trade Organization: A foreign influence approach. Retrieved from: https://www.tandfonline.com/doi/ abs/10.1080/09638190903327302.

9. Flissak, K. A. (2016). Interstate trade disputes, and a role of economic diplomacy in the process of their regulation. Aktualni problemy mizhnarodnykh vidnosyn, 127, 152-164.

10. Charnovitz, S. (n.d.). Triangulating the World Trade Organization. Retrieved from: https://www.cambridge.org/core/ journals/american-journal-of-international-law/article/triangulating-the-world-trade-organization/3FD609A306AF0 AC4DB0A34C5D43F2A0E.

11. World Trade Organization (n.d.). Retrieved from: https:// www.the WTO.org.

12. ePing-SPS \& TBT notification alert system (n.d.). Retrieved from: http://www.epingalert.org/en.

\section{Інструментарій СОТ у регулюванні міждержавного торговельно-економічного співробітництва}

\section{Н. Г. Калюжна ${ }^{1}$, А. О. Ходжсаян ${ }^{2}$, П. Г. Неботов ${ }^{3}$}

1 - Київський національний торговельно-економічний університет, м. Київ, Україна, e-mail: kalujnaya.natalya@ gmail.com

2 - Київський національний університет імені Тараса Шевченка, м. Київ, Україна, e-mail: alina_khodzhaian@ukr.net 3 - Державний науково-дослідний інститут інформатизації та моделювання економіки, м. Київ, Україна, е-mail: petr_nebotov@ukr.net

Мета. Визначення сутності й результативності застосування інструментів СОТ як засобу попередження та врегулювання торговельних конфліктів, що виникають у процесі міждержавного торговельно-економічного співробітництва.

Методика. Методологічною основою дослідження послугували методи аналізу й синтезу, що використані для систематизації даних щодо надходження нотифікацій і запитів на врегулювання торговельних суперечок у рамках СОТ протягом 1995-2018 рр. Формалізацію критеріїв результативності застосування інструментів СОТ здійснено за допомогою методу математичного моделювання. Метод статистичного аналізу використано для підтвердження висхідного лінійного тренду в динаміці щорічної кількості нотифікацій СОТ у період 1995-2018 pp.

Результати. Обгрунтована визначальна роль СОТ у врегулюванні торговельно-економічного співробітництва держав. Показано, що метою використання інструментів СОТ є мінімізація кількості та ступеня інтенсивності міждержавних конфліктів у торговельній площині. Розглянута сутність системи нотифікацій і механізму врегулювання торговельних суперечок як визначальних складових інструментарію попередження торговельних конфліктів у рамках СОТ. Визначено критерій результативності системи нотифікацій СОТ як щорічне збільшення кількості поданих нотифікацій, та засвідчено його дотримання протягом 1995-2018 рр. Запропоновані статичний і динамічний критерії результативності механізму врегулювання торговельних суперечок СОТ. Підтверджено, переважно, дотримання статичного критерію, що свідчить про дієвість механізму врегулювання суперечок як інструменту глобальної торгівлі СОТ. Засвідчено не- 
виконання динамічного критерію, що може інтерпретуватися як відсутність кумулятивного ефекту від накопичення досвіду врегулювання торговельних суперечок. Запропоновано комплексний критерій результативності застосування інструментів СОТ і проаналізовано його дотримання протягом 1995-2018 рр. Визначені пріоритетні напрями врегулювання міждержавного торговельно-економічного співробітництва з боку СОТ.

Наукова новизна. Уперше запропоновано методичний підхід до оцінювання результативності інструментарію СОТ як засобу врегулювання міждержавного торговельно-економічного співробітництва, в основу якого покладено: обгрунтування критеріїв результативності застосування таких інструментів торговельного захисту, як система нотифікацій та механізм врегулювання торговельних суперечок СОТ; формулювання комплексного критерію результативності застосування інструментів СОТ; визначення кількісних еквівалентів запропонованих критеріїв та аналізування їх дотримання протягом 1995-2018 pp.

Практична значимість. Запропонований методичний підхід може бути застосований для оцінювання результативності інструментарію СОТ щодо врегулювання глобальної торгівлі в частині попередження й подолання міждержавних торговельних конфліктів.

Ключові слова: глобальні правила торгівлі, торговельний конфлікт, торговельно-економічне співробітництво, система нотифікацій, коефіцієнт результативності

\section{Инструментарий ВТО в регулировании межгосударственного торгово- экономического сотрудничества}

\section{Н. Г. Калюжная ${ }^{1}$, А. А. Ходжаян ${ }^{2}$, П. Г. Неботов ${ }^{3}$}

1 - Киевский национальный торгово-экономический университет, г. Киев, Украина, e-mail: kalujnaya.natalya@ gmail.com

2 - Киевский национальный университет имени Тараса Шевченко, г. Киев, Украина, e-mail: alina_khodzhaian@ $\underline{\text { ukr.net }}$

3 - Государственный научно-исследовательский институт информатизации и моделирования экономики, г. Киев, Украина, e-mail: petr_nebotov@ukr.net

Цель. Определение сущности и результативности применения инструментов ВТО как средства упреждения и урегулирования торговых конфликтов, возникающих в процессе межгосударственного торгово-экономического сотрудничества.

Методика. Методологической основой исследования послужили методы анализа и синтеза, используемые для систематизации данных о поступлении нотификаций и запросов на урегулирование торговых споров в рамках ВТО в течение 1995-2018 гг. Формализация критериев результативности применения инструментов ВТО осуществлена с помощью метода математического моделирования; метод статистического анализа использован для подтверждения восходящего линейного тренда в динамике ежегодного количества нотификаций ВТО в период 1995-2018 гг.

Результаты. Обоснована определяющая роль ВТО в урегулировании торгово-экономического сотрудничества государств. Показано, что целью использования инструментов ВТО является минимизация количества и степени интенсивности межгосударственных конфликтов в торговой плоскости. Рассмотрена сущность системы нотификаций и механизма урегулирования торговых споров как определяющих составляющих инструментария предупреждения торговых конфликтов в рамках ВТО. Определен критерий результативности системы нотификаций ВТО как ежегодное увеличение количества поданных нотификаций, и засвидетельствовано его соблюдение в течение 1995-2018 гг. Предложены статический и динамический критерии результативности механизма урегулирования торговых споров ВТО. Подтверждено, преимущественно, соблюдение статического критерия, что свидетельствует о действенности механизма урегулирования споров как инструмента глобальной торговли ВТО. Засвидетельствовано невыполнение динамического критерия, что может интерпретироваться как отсутствие кумулятивного эффекта от накопления опыта урегулирования торговых споров. Предложен комплексный критерий результативности применения инструментов ВТО и проанализировано его соблюдение в течение 1995-2018 гг. Определены приоритетные направления урегулирования межгосударственного торгово-экономического сотрудничества со стороны ВТО.

Научная новизна. Впервые предложен методический подход к оценке результативности инструментария ВТО как средства урегулирования межгосударственного торгово-экономического сотрудничества, в основу которого положено: обоснование критериев результативности применения таких инструментов торговой защиты, как система нотификаций и механизм урегулирования торговых споров ВТО; формулировка комплексного критерия результативности применения инструментов ВТО; определение количественных эквивалентов предложенных критериев и анализ их соблюдения в течение 1995-2018 гг.

Практическая значимость. Предложенный методический подход может быть применен для оценки эффективности инструментария ВТО по урегулированию глобальной торговли в части предупреждения и преодоления межгосударственных торговых конфликтов.

Ключевые слова: глобальные правила торговли, торговый конфликт, торгово-экономическое сотрудничество, система нотификаций, коэффициент результативности

Recommended for publication by V.P. Onyshchenko, Doctor of Economic Sciences. The manuscript was submitted 30.05.19. 